\title{
PERUBAHAN FUNGSI RUANG TANEYAN LANJHANG PADA MASYARAKAT MIGRAN MADURA DI DESA KRAJAN JEMBER
}

\author{
Abraham Mohammad Ridjal \\ aang_utd@yahoo.com
}

\begin{abstract}
ABSTRAK
Manusia merupakan salah satu objek yang sangat dinamis dan mudah menyesuaikan dengan perubahan-perubahan yang terjadi dalam kehidupannya, termasuk faktor lingkungan dan kebutuhan. Hal ini tentu sangat berpengaruh juga dalam pola kehidupan ber-arsitektur yang telah mereka bangun dan taati selama beberapa abad. Selain itu, manusia juga memiliki kekuatan dan kemampuan untuk membentuk dan mengendalikan pola kehidupan ber-arsitektur yang disesuaikan dengan kebutuhan dan kondisi dirinyauntuk bisa menciptakan suasana dan kondisi yang nyaman bagi mereka. Taneyan lanjhang adalah salah satu contoh dari terbentuknya kehidupan ber-arsitektur yang terkait dengan kehidupan masyarakat tradisional Madura. Peran penting kehidupan manusia dapat terlihat dari pola ruang yang terbentuk di dalamnya, seperti hirarki ruang yang jelas terlihat antara ruang publik yang didominasi oleh kelompok pria dengan ruang privat yang didominasi oleh kelompok wanita. Konsekuensi akan pembentukan dan penerapan budaya arsitektur tersebut bukan tanpa makna, karena semua hal tersebut seakan sudah diatur dalam norma yang berlaku dalam kehidupan masyarakatnya, apalagi masyarakat Madura dikenal memiliki sikap fanatisme yang cukup kuat dalam mengendalikan sikap dan perilaku mereka. Oleh karena itu, jika perubahan pola kehidupan dan lingkungan yang ada di sekitar mereka, apakah hal ini mampu merubah juga sikap dan penempatan dirinya terhadap pola ruang arsitektur yang sudah mereka bentuk dan terapkan selama ini, ataukah arsitektur mereka perlakukan sebagai objek yang harus mengikuti perubahan perilaku dan pola kehidupan mereka saat ini?
\end{abstract}

Kata kunci: manusia, ber-arsitektur, madura, taneyan lanjhang

\begin{abstract}
ABSTRACK
Exodus by Madurese people to Java, represented one of the resident disseminating process in Indonesia. Besides transfer of human beings, there were also architecture and culture transfer, especially house remain was important shares in human life. The aim of this architecture's research is to know changes of architecture that happened in two cultures in its life pattern. Though culture that goes on it follows local culture, however its architecture's orientation does not stem from the same culture, and so does on the contrary. This matter represent there are values that able to perceive physically on the elements of architecture, and also its influence on its pattern habit of society exist in depth.This research represents a kind of study and object case research, by determining one of the research object and conduct it with in depth study to get required data to analyse. Besides, this research also represents a qualitative research to describe and compare of two architectures. In course of analysis, quantitative data also needed, which obtained from questioner concerning architecture composition. By the existence of existing change and difference gotten after analysis process by compare of two architecture, showed that architecture have a dynamically character. Besides, the change and its dynamically was supported by a very good relationship between architecture, human being and environment where the architecture woke up.
\end{abstract}

Keywords: Madurese architecture, culture, environment 


\section{Pendahuluan: Bagaimana Masyarakat Migran Beradaptasi?}

Arsitektur tradisional Madura merupakan salah satu ciri khas yang dimiliki oleh arsitektur Jawa Timur. Arsitektur rumah tinggal ini didukung oleh masyarakat yang secara keseluruhan memeluk agama yangsama, yaitu Islam, akan tetapi mereka memiliki orientasi yang berbeda dalam berbudaya (Wiryoprawiro, 1986). Hal tersebut nampak pada penampilan rumah tinggal tradisionalnya.

Sepanjang sejarah perjalanan masyarakat Madura, telah terjadi perpindahan secara besar-besaran, baik untuk selamanya ataupun sementara waktu menuju pulau Jawa maupu pulau-pulau lain di Nusantara. Hageman dalam Jonge (1989) menyebutkan bahwa terdapat sekitar 833.000 orang Madura yang bermukim di Jawa Timur pada pertengahan abad yang lalu. Hal ini jauh lebih banyak dari jumlah penduduk asli di Pulau Madura. Dengan banyaknya arus perpindahan masyarakat Madura ke Pulau Jawa, hal tersebut dapat disertai juga dengan perpindahan arsitektur yang mereka bawa dari tanah kelahirannya, karena kehadiran dan peranan rumah tinggal sangat penting bagi kehidupan manusia seutuhnya. Di lain pihak, rumah tinggal merupakan bagian yang tidak terpisahkan dari arsitektur yang amat penting bagi kehidupan manusia.

Rapoport dalam Snyder and Catanese(1979) menjelaskan bahwa pada awalnya arsitektur memang terkait dengan bangunan, terutama untuk tempat tinggal yang dalam hal ini banyak dimasukkan unsur adat dan budaya masyarakat yang bersangkutan, sehingga pembuatannya tidak bisa terlepas dari unsur adat istiadat yang berlaku. Dengan demikian, perpindahan masyarakat Madura ke Pulau Jawa, akan diikuti pula dengan perpindahan arsitekturnya.

Dengan perbedaan kondisi lingkungan antara Pulau Jawa dan Madura, hal tersebut sangat memungkinkan adanya perubahan dan pergeseran dalam ber-arsitektur. Sehingga bukan tidak mungkin hal tersebut menjadi salah satu dasar munculnya perbedaan-penyesuaian arsitektur yang terdapat di tanah rantau.

Penulisan ini bertujuan untuk mengungkap salah satu faktor yang sering terjadi dalam berkehidupan ber-arsitektur dalam masyarakat, yaitu adaptive architecture. Fenomena ini merupakan salah satu gambaran umum yang hampir selalu terjadi, namun sering diabaikan dalam pembelajaran arsitektur.

\section{Kajian Pustaka dan Metode}

\subsection{Pembelajaran 'Dinamika Ruang' pada Living Architecture}

Arsitektur merupakan bagian yang tidak terpisahkan dalam hidup manusia. Dalam berarsitektur, manusia tidak pernah bisa melepaskan diri dari batasan dan hukum-hukum alam yang da di sekitarnya. Karena iklim dan kondisi alam tersebut merupakan salah satu faktor utama dalam membentuk cara hidup manusia dalam bertahan hidup, atau bahkan budaya yang ada dalam kehidupa manusia. Kondisi alam yang berbeda pada masing-masing daerah akan membentuk cara hidup dan budaya yang berbeda pula, demikian juga dengan arsitektur yang berkembang dalam masyarakatnya. 
Kegiatahn ber-arsitektur pertama yang melekat dalam kehidupan manusia adalah berhuni, karena hal tersebut merupakan kebutuhan yang mendasar bagi kehidupan manusia yang beradab (Wiryoprawiro, 1986). Seperti yang diungkapkan oleh Rapoport (1969), bahwa arsitektur semula lahir untuk menciptakan tempat tinggal sebagai wadah untuk perlindungan manusia dari gangguan lingkungan; alam dan binatang. Kemudian Crowe (1997) melanjutkan dengan menjelaskan bahwa bentuk dan fungsi bangunan adalah respon yang diberikan oleh manusia dalam interaksinya dengan lingkungan sekitarnya. Dalam perkembangannya, respon yang diberikan oleh manusia memiliki keragaman, tergantung dari tempat dimana mereka tinggal. Hal inilah yang menunjukkan keragaman arsitektur sebagai bentukrespon terhadap kondisi lingkungan.

Semakin berkembangnya suatu peradaban, maka hunian atau rumah tinggal sebagai bagian dari kegiatan ber-arsitektur - pun menjadi semakin kompleks peran dan fungsinya. Oleh karena itu, tidak heran kalau beberapa symbol-pun diterapkan untuk memberikan tanda atau identitas pada huniannya. Selain itu, pemahaman dan pengamatan terhadap manusia merupakan langkah yang harus diambil juga dalam menjadikan arsitektur sebagai identitas lingkungan binaan (Ridjal, 2011).

Dinamika kehidupan dalam bermasyarakat selalu mengalami perubahan tergantung dari situasi dan kondisi yang berkembang dalam masyarakat dari waktu ke waktu. Hal ini tidak mungkin menjadikan tradisi (tradtio, yang berarti diteruskan atau kebiasaan dalam bahasa latin) menjadi sesuatu yang bersifat freeze atau tetap. Akan tetapi tradisi menjadi sesuatu yang bersifat unfreeze atau selalu mengalami perubahan, tetapi dalam bentuk dasar yang sama. Demikian juga dalam berarsitektur, manusia senantiasa menjadikan arsitektur menjadi jembatan yang menghubungkan antara kebutuhan mereka akan alam dan penyesuaiannya. Dalam hal ini, arsitektur dapat berfungsi sebagai suatu tanda akan kehadiran suatu kebudayaan. Sebagaimana diungkapkan oleh Mangunwijaya (1992), bahwa terdapat tingkatan makna dan nilai yang dimiliki oleh suatu tempat, artinya ada yang paling penting, ada yang kurang penting, bahkan ada pula yang tidak ada nilainya sama sekali. Pemahaman akan citra dan nilai yang dimiliki oleh suatu tempat tersebut, dapat menjadi suatu tuntunan dalam perancangan arsitektur. Hal tersebut merupakan suatu wujud peran arsitektur dalam membentuk dan mewarnai budaya yang berkembang dalam masyarakat.

\subsection{Arsitektur Sebagai Artefak Budaya Yang Representatif}

Munculnya arsitektur di tengah-tengah kehidupan masyarakat, merupakan suatu system yang saling terkait satu sama lain. Keberadaan arsitektur dalam masyarakat juga ikut mewarnai pola budaya yang berkembang di dalamnya. Dalam hal ini, budaya merupakan sesuatu yang sangat terkait dengan pergerakan waktu atau sejarah. Jika kita mengamati sebuah bangunan tradisional, maka sangat jelas terlihat adanya perjalanan sejarah yang mengingatkan kita pada nilai kebudayaan pada masa tertentu.

Keterkaitan antara arsitektur dengan manusia, menguatkan penjelasan Ballantyne (2002: 12) bahwa sebuah bangunan dapat disebut sebagai arsitektur, tergantung dari apa yang kita rasakan terhadap bangunan tersebut. Jadi hal tersebut dapat terjadi pada semua bangunan yang dapat kita rasakan. Dalam hal ini, arsitektur bahkan bisa menjadi semacam pemberitahuan atau gambaran dari budaya masyarakat. Pengertian ini juga dijelaskan oleh Hersberger dalam Laurens (2004) bahwa pemahaman seseorang akan suatu objek atau lingkungan, berkaitan dengan kualitas emosional seseorang terhadap objek atau lingkungan tersebut. Hal ini menunjukkan antara arsitektur dan manusia memiliki kerkaitan yang sangat erat. Oleh karena itu, 
Crowe (1997) menjelaskan bahwa bentuk dan wujud arsitektur merupakan gambaran dari adanya interaksi yang terjadi antara manusia dengan lingkungan sekitarnya. Penjelasan ini semakin memperkuat hubungan antara arsitektur dengan manusia dan perkembangannya.

Dalam arsitektur tradisional, Rapoport (1969) dapat dijumpai pola tatanan pemukiman yang berbeda-beda, dengan tingkat kesakralan tertentu. Hal ini menunjukkan adanya pengaruh budaya dan lingkungannya terhadap arsitektur tradisional. Menurut Soeroto (2003: 24), arsitektur tradisional merupakan bagian dari kebijakan dan kearifan pembangunan ruang hidup masyarakat, karena keberadaannya sangat lekat dengan keseharian masyarakat tradisional yang masih menganut kehidupan kolektif. Akan tetapi, sebagaimana arsitektur yang lain, arsitektur tradisional juga mengalami perubahan dan pembaharuan, meskipun sangat lambat.

\subsection{Metode Pengamatan Perubahan Pola Ruang pada Arsitektur Padhalungan}

Pengamatan ini merupakan suatu proses pengkajian terhadap perubahan arsitektur Madura yang ada di Jawa. Langkah awal yang dilakukan dalam penelitian ini adalah dengan survei pendahuluan untuk mencari lokasi penelitian yang menggambarkan perubahan pola hunian sebagai bentuk adaptasi masyarakat dengan kondisi alam yang baru.

Pengamatan ini dilakukan dengan melakukan in depth study guna mengetahui dan mengidentifikasi pola hunian yang terjadi pada masyarakat migrant, dalam hal ini adalah masyarakat padhalungan atau medhalungan, yang berada di desa Krajan kelurahan Tegalgede kecamatan Sumbersari Jember. Tujuan dari penelitian ini adalah untuk memberikan gambaran secara lengkap dan menyeluruh untuk menggambarkan hubungan antara adaptasi masyarakat terhadap kondisi alamnya.

Pengamatan ini juga dibantu oleh data pendukung mengenai informasi arsitektur induk, yaitu Arsitektur Madura (dalam hal ini adalah pola hunian masyarakat Sampang, Madura sebagai cikal bakal dari lahirnya perkampungan di lokasi studi). Selain itu, pengamatan juga dilakukan untuk mengetahui beberapa aspek yang didasarkan pada data yang tidak terukur, seperti mengetahui makna, proses perubahan ruang, pola penggunaan ruang dan kehidupan masyarakatnya. Dalam hal ini perolehan data yang digunakan tidak berdasarkan ukuran, namun setelah proses lapangan selesai dilakukan, tetap diperlukannya proses kuantifikasi data untuk tahap analisa data (Darjosanjoto, 2006: 37).

\section{Hasil dan Pembahasan}

\subsection{Padhalungan: Representasi Masyarakatyang Adaptif}

Desa Krajan merupakan bagian dari kelurahan Tegal Gedhe, kecamatan Sumbersari, Jember. Di wilayah ini memiliki mayoritas penduduk yang merupakan suku Madura, sehingga bahasa daerah yang biasa terdengar disini adalah bahasa Madura, sebagai bahasa pengantar mereka sehari-hari.

Pada area peneitian, terdapat sebuah perumahan baru yang dibangun pada awal tahun 1980-an, telah ikut mewarnai pola hidup dan arsitektur masyarakatnya, terutama yang bersebelahan persis dengan perumahan baru tersebut. Perumahan yang dihuni oleh sebagian masyarakat pendatang dari Jawa (Ponorogo, Nganjuk, Surabaya) dan sebagian lagi masyarakat pendatang dari Madura, atau biasa disebut Padhalungan atau 
Medhalungan(penyebutan istilah ini diberikan oleh masyarakat local terhadap pendatang dari Madura, yang berarti medhal atau keluar dan lungan atau pergi). Pengamatan ini menjadi menarik, karena pada masyarakat Padhalungan ini mereka memiliki induk arsitektur yang berbeda dengan arsitektur endemiknya (yaitu Jawa, berbeda dengan pendatang lain yang memang berasal dari Jawa sebelah Barat). Akan tetapi, reaksi adaptif yang ditunjukkan oleh masyarakat Padhalungan tidak hanya duplikasi untuk menggambarkan eksistensi mereka, dimana Wilkinson (2013) menggambarkan sebagai langkah expressionism sebagai metoda untuk menunjukkan jati diri desain melalui lines, shapes maupun materials. Akan tetapi, eksistensi yang mereka hadirkan lebih merupakan sebagai upaya adaptif terhadap kondisi alam baru yang mereka tempati.

Kelompok rumah yang ada di kawasan ini disebut Koleman atau Taneyan kalau di Madura, yaitu kelompok rumah yang merupakan satu keluarga atau seketurunan, yang biasa terdiri dari 3 sampai 5 rumah disertai dengan satu langgar sebagai tempat beribadah. Selain itu juga terdapat kandhang dan dapur yang lokasinya sudah berubah, dari depan rumah menjadi bagian rumah yang letaknya di belakang.

Perubahan-perubahan lain yang terjadi adalah pola ruang dalam rumah. Dalam hal ini, beberapa bagian rumah ada yang berubah fungsi, akan tetapi ada juga yang memiliki fungsi tetap, namun posisinya berubah seiring perubahan yang berlangsung dalam rumah mereka.

\subsection{Koleman sebagai Bentuk Baru dari Taneyan Lanjhang}

'Koleman' berasal dari kata 'kolem' merupakan kata yang diambil dari bahasa madura yang berarti kumpul, atau kelompok. Dengan demikian Koleman adalah sebuah kata keterangan yang menyatakan tempat, yaitu tempat untuk berkumpul. Dalam hal ini tidak dijelaskan secara spesifik mengenai bentuk dari tempat tersebut, sehingga Koleman bisa jadi merupakan sebuah kelompok rumah yang masih memiliki ikatan tertentu, tanpa harus memiliki ciri khas dalam hal bentuk atau pola tertentu. Berbeda dengan 'Taneyan lanjang' yang berasal dari kata 'Taneyan' yang berarti halaman dan 'lanjang' yang berarti panjang atau memanjang. Sehingga dapat digambarkan secara spesifik perbedaannya yaitu Taneyan lanjang memiliki bentuk spesifik yang memanjang, karena memiliki pengertian sebagai halaman yang memanjang.

Kelompok rumah atau Koleman yang terlihat pada permukiman orang Madura yang berada di Jember dibangun secara berdekatan dengan berkelompok satu sama lain dan saling berdekatan. Dalam satu kelompok rumah, selalu terdapat langgar seperti Taneyan lanjang di Madura. Beberapa bahkan masih memiliki bentuk dan pola yang masih sama dengan Taneyan lanjang di Madura. Selain langgar, dalam satu kelompok rumah biasanya juga terdapat kandang atau bahkan dapur umum yang terpisah dari rumah. 


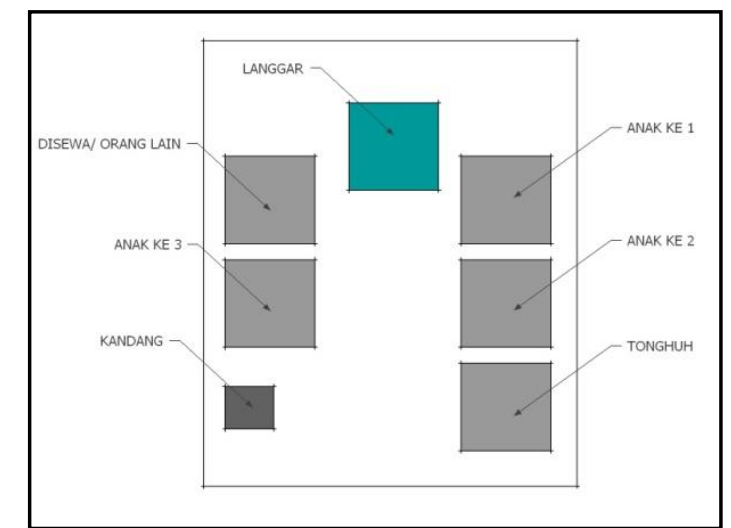

Gambar 1. Lay-out Koleman yang Menyerupai Bentuk Taneyan lanjhang (Sumber: Ridjal, 2012)

Koleman biasanya diawali dengan adanya tonghuh atau rumah orang tua yang pertama kali dibangun dalam Koleman tersebut. Biasanya nama orang tua itu yang akan menjadi nama Koleman tersebut, seperti "Koleman pak Alwi", disini menunjukkan bahwa penghuni Koleman tersebut adalah keturunan dari pak Alwi. Posisi rumah biasanya terletak di sebelah timur dari lahan yang tersedia, hal ini untuk menunjukkan btas lahan yang dimilikinya, selain itu juga posisinya yang dekat dengan "sabeh" atau area persawhan yang berada di sebelah timur lahan tempat mereka tinggal. Setelah dibangun tonghuh, kemudian dibangun langgar yang letaknya selalu berada di sebelah barat. Setelah terbangunnya tonghuh dan langgar, kemudian jika generasi seterusnya menempati lahan yang sama, maka akan terbentuk Koleman. Dalam satu generasi, Koleman akan menyerupai Taneyan, yaitu dengan posisi langgar di sebelah barat, rumah di sebelah utara. Perbedaan utama dengan Taneyan adalah arah perkembangannya yang tidak berjalan ke timur, tetapi menempati ruang antara tonghuh dan langgar. Hal ini dikarenakan suku Madura yang tinggal di Jember merupakan pendatang, sehingga lahan yang mereka miliki untuk tempat tinggalnya juga terbatas.

Jadi, untuk melacak rumah pertama dalam satu Koleman, dapat dilacak melalui susunan penghuninya. Posisi tonghuh atau rumah pertama selalu berada di daret rumah sebelah utara, dam menempati posisi paling timur sebagai pembatas Koleman. Meskipun bentuk Koleman sudah melebar dan berkembang, tetapi posisi tonghuh selalu berada di sebelah utara dan dengan deret rumah yang paling timur sebagai pembatas lahan permukiman.

Pola susunan rumah dalam Taneyan juga terlihat dalam Koleman, terutama dalam menentukan posisi tonghuh atau rumah orang tua. Jika dalam Taneyan rumah orang tua diposisikan di sebelah barat - sebagai ruang suci - bersebelahan dengan langgar, berbeda dengan Koleman yang menempatkan rumah orang tua di sebelah timur, karena berhubungan langsung dengan lahan pertanian yang berada di sebelah timur hunian. Meskipun terdapat perbedaan dalam menentukan posisi timur dan barat, tetapi kesamaan terlihat dari arah hadap rumah tonghuh yang menghadap ke arah utara, sama seperti rumah dalam Taneyan, meskipun terdapat beberapa Koleman yang berbeda, tergantung dari bentuk dan luas lahan yang mereka miliki. 


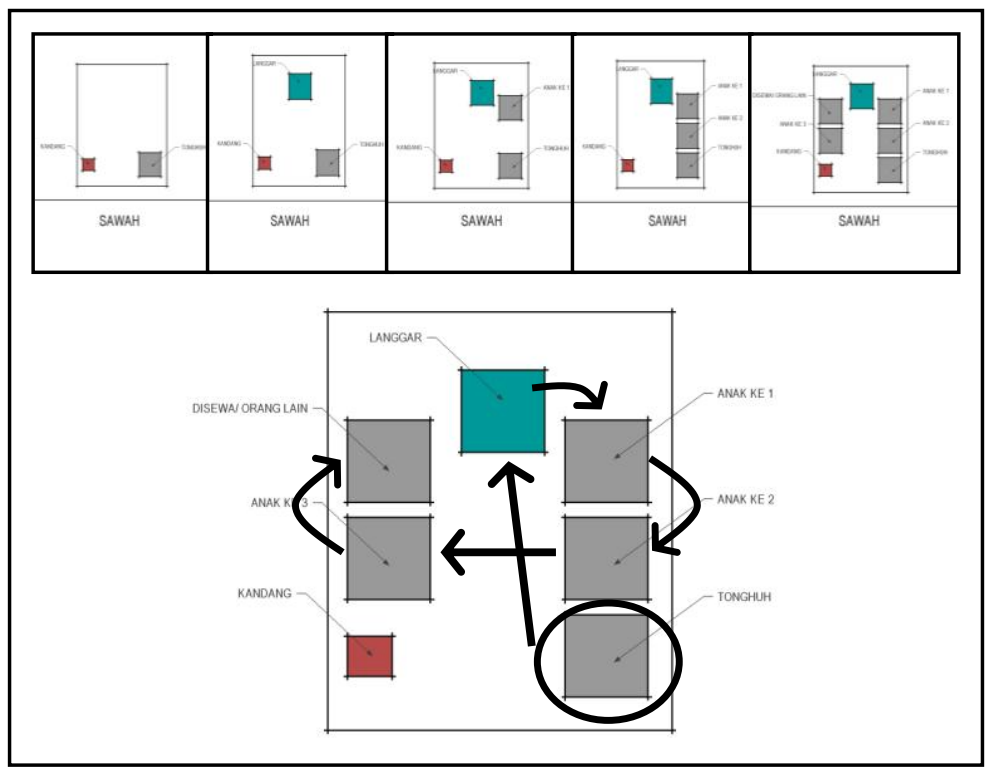

Gambar 2. Tahap Perkembangan Koleman Menggambarkan Eksistensi Tonghuh dan Musholla (Sumber: Ridjal, 2012)

Gambaran dari pola susunan Koleman juga memiliki kemiripan dengan Taneyan lanjang, akan tetapi dengan permasalahan baru, yaitu keterbatasan lahan dan bertambahnya jumlah anggota keluarga, maka penerapan pola Taneyan lanjang sudah mengalami pergeseran. salah satu hal yang paling menonjol adalah pola perkembangan dari Koleman yang berbeda dengan Taneyan lanjang. Pola perkembangan Taneyan lanjang selalu dimulai dengan adanya hunian dan langgar di sebelah barat, kemudian bergerak ke arah timur. Hal ini menunjukkan posisi orang tua yang berada di Barat, memiliki nilai yang disucikan dan ditinggikan, karena selain barat dianggap sebagai kiblat dari segala urusan agama, juga terdapat langgar sebagai simbol kualitas keagamaan kelompok. Berbeda dengan Koleman yang memiliki posisi tonghuh (rumah orang tua) di ujung paling timur, sehingga jauh dari langgar sebagai simbol kesucian dan kualitas agama kelompok mereka. Hal ini dikarenakan keterbatasan lahan yang mereka miliki, sehingga langkah yang sudah dilakukan sejak awal oleh orang tua mereka adalah dengan membangun rumah di ujung paling timur dan langgar di ujung paling barat, sebagai penanda dari batas kepemilikan lahan yang mereka miliki. Kondisi seperti ini menggambarkan adanya perubahan dari konsep ber-arsitektur mereka dikarenakan kondisi yang mereka hadapi tidak memungkinkan untuk menciptakan ruang arsitektur yang seharusnya.

\subsection{Koleman sebagai Bentuk Eksistensi Adaptif Masyarakat Padhalungan}

Eksistensi masyarakat Madura sudah tercatat pada hampir semua sejarah peradaban maupun catatan sosiologi dan antropologi bangsa ini. Hal ini dikarenakan kerajaan Madura merupakan sebuah kerajaan besar yang mampu bersanding, bahkan ber-mitra dengan kerajaan besar di nusantara, yaitu Majapahit (Graaf dan Pigeaud, 1974). Oleh karena itu, bukan tidak mungkin ketika eksodus masyarakat Madura yang dating ke pulau Jawa atau pulau lain di Nusantara ini akhirnya memunculkan tipologi baru dari hunian masyarakat Madura.

Jika merujuk pada bahasan mengenai pola hunian, maka dapat dilihat pola awal hunian masyarakat Madura adalah Taneyan Lanjhang, dimana penamaan pola hunian ini berasal dari perwujudan atau bentuk hunian secara fisik. Akan tetapi, pola taneyan 
lanjhang ini memiliki makna yang cukup besar sebagai pembentuk hunian dengan type communal space. Selain itu, pemaknaan dan pesan yang disematkan pada penataan hunian tersebut juga dapat dipahami sebagai gambaran dari kehidupan masyarakat Madura secara arif.

Pergeseran dan perubahan waktu secara otomatis akan diikuti juga dengan perubahan tuntutan akan kebutuhan dan kondisi bermasyarakat, apalagi bagi masyarakat yang hidup di lokasi migrant (lokasi baru dengan kondisi alam yang berbeda dari sebelumya), seperti yang terjadi pada masyarakat Padhalungan.

Perpindahan lokasi hunian yang baru, biasanya memang dibarengi dengan persandingan antara budaya induk atau asal dengan kondisi alam dan budaya yang baru. Oleh karena itu, adaptasi yang dilakukan dan dialami oleh beberapa kelompok masyarakat juga akan mengalami perbedaan antara satu kasus dengan lainnya. Dalam hal ini, masyarakat Padhalungan desa Krajan, Jember beradaptasi dengan menghadirkan kembali pola hunian, akan tetapi dengan penekanan yang berbeda.

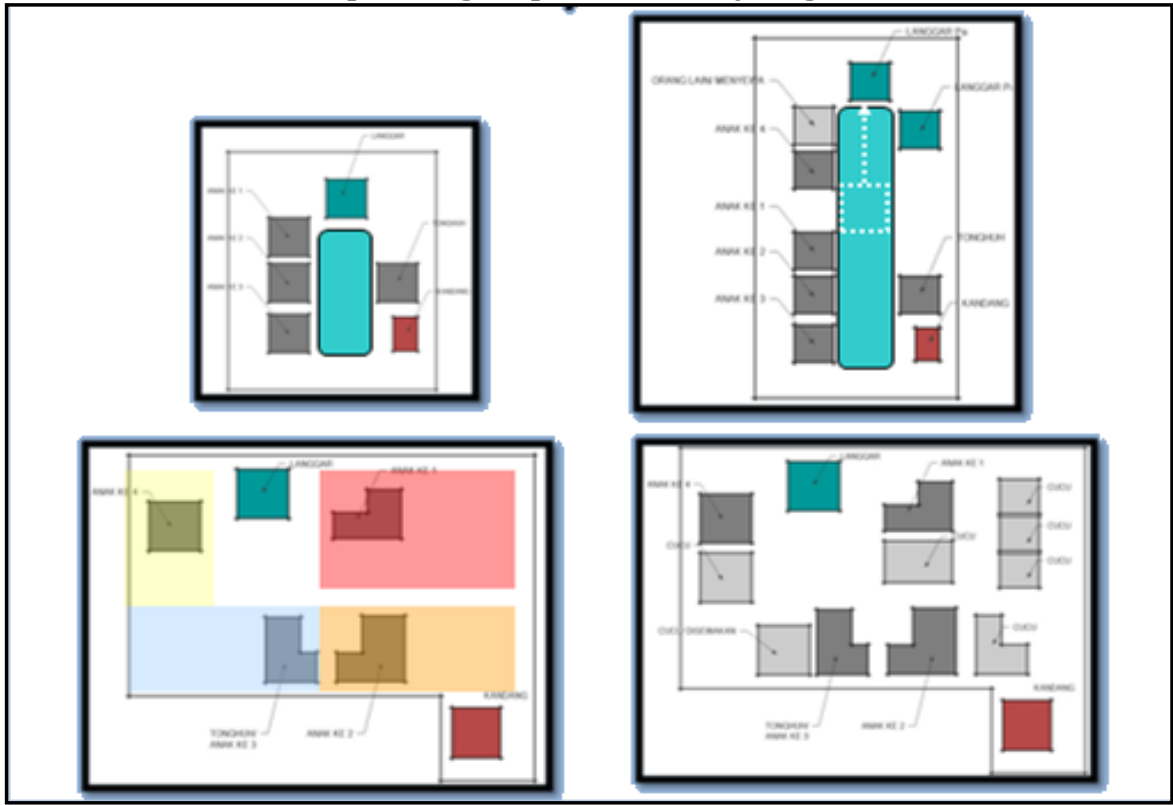

Gambar 3. Variasi Pola Koleman yang Menekankan pada Fungsi Communal Spacemelalui Kelompok Hunian

Munculnya istilah Koleman memberikan makna penekanan terhadap fungsi hunian. Pergeseran gaya hidup, kebutuhan, tuntutan hidup seolah menjadi dasar dari ditekankan lagi eksistensi makna berhuni bagi masyarakat Madura, yaitu kebersamaan dalam communal living. Jika merujuk dari arti kata Koleman yang berarti berkumpul, menunjukkan penekanan terhadap fungsi hunian. Hal ini berbeda dengan arti kata Taneyan lajhang yang berarti halaman panjang, yang menekankan pada lokasi atau tempat. Oleh karena itu, penamaan tersebut bukan sekedar istilah baru, akan tetapi lebih pada upaya untuk mengembalikan kembali fungsi berhuni seperti pada konsep dasar hunian masyarakat Madura. Dengan demikian, salah satu langkah awal adalah menjaga eksistensinya melalui penekanan nama huniannya, agar keberadaan communal space dalam living mereka tidak semakin mengarah pada individual living.

Dengan demikian, hal tersebut dapat terlihat dari variasi pola hunian pada Koleman yang tidak menekankan pada bentuk halaman yang memanjang, akan tetapi lebih pada terciptanya sebuah gugusan atau kelompok hunian yang dihuni secara bersama-sama. 


\section{Simpulan}

Ruang yang terbentuk dalam arsitektur Madura memiliki nilai yang sangat penting, karena dibangun berdasarkan konsep kehidupan yang berlangsung dalam lingkungan mereka. Seperti konsep Taneyan lanjang yang memiliki beragam nilai yang terkandung di dalmnya. Perkembangan dan perubahan yang terjadi dalam arsitektur akan terjadi seiring dengan perjalanan waktu dan perubahan lokasi dimana manusia tinggal. Seperti yang terjadi di desa Krajan, dimana pola kehidupan berarsitektur orang Madura disini sudah terdapat beberapa perbedaan mendasar dalam membangun arsitektur.

Jika berbicara mengenai arsitektur Madura, tentu tidak pernah lepas dengan istilah Taneyan, karena Jonge (1987: 13) mengatakan bahwa pola hunian yang banyak ditemukan dalam arsitektur Madura adalah bentuk Taneyan. Hal ini merupakan ciri khas yang dimiliki oleh arsitektur Madura. Perubahan dari Taneyan dapat terlihat dari bentuk pola penataan rumahnya, selain itu juga tahap perkembangan yang sarat dengan makna dalam arsitekturnya.

Perbedaan yang paling mendasar adalah bentuk antara Taneyan dan Koleman, terutama jika melihat posisi rumah orang tua yang pertama kali dibangun. Hal ini jelas menunjukkan adanya faktor keterbatasan lahan yang mereka miliki ketika berada di tanah rantau (Jawa). Selain itu, ruang yang terbentuk antara Taneyan dan Koleman juga terdapat perbedaan, salah satunya dari nama yang mereka berikan bagi kelompok hunian mereka. Taneyan yang berarti halaman atau Lanjang yang berarti panjang, menunjukkan bentuk pola hunian yang terbentuk berdasarkan ruang luar mereka yang memanjang dari barat ke timur, berbeda dengan Koleman yang berarti kumpul, yang menunjukkan pola hunian yang mengumpulkan beberapa rumah dalam satu kelompok tertentu.

\section{Daftar Pustaka}

Ballantyne, Andrew. 2002. What is Architecture? New York: Routledge.

Crowe, Norman. 1997. Nature and the Idea of a Man-Made World. London: MIT Press.

Darjosanjoto, Endang T.S. 2006. Penelitian Arsitektur di Bidang Perumahan dan Permukiman. Surabaya: ITS Press.

Faqih, Muhammad. 2005. Domestic Architecture and Culture Change: Re-ordering the Use Space in Madurese Housing. Newcastle: University of Newcastle Press.

Graaf, HJ de dan Pigeaud, Th.G.Th. 1974. Kerajaan-Kerajaan Islam Pertama di Jawa. Jakarta: PT. Pustaka Graffiti Press.

Jonge, Huub de. 1989. Madura dalam Empat Zaman: Pedagang, Perkembangan Ekonomi dan Islam. Jakarta: PT. Gramedia.

Laurens, Joyce Marcella. 2004. Arsitektur dan Perilaku Manusia. Jakarta: PT. Gramedia. Rapoport, Amos. 1969. House Form and Culture. Englewood Cliffs, NJ, Prentice Hall.

Ridjal, Abraham Mohammad.2011. Learning Architecture from Our Ancestors. Kyoto: SUSTAIN 2011 Proceedings.

Ridjal, Abraham Mohammad. 2012. Membangun Jembatan antara Buku dan Praksis Arsitektur.Jurnal RUAS Vol 10 no.2 tahun 2012.

Ridjal, Abraham Mohammad. 2012. Change the Meaning of Space in Taneyan Represents Dynamic Patterns of Space in Madura Architecture. Brastagi: ICCSTUDN Proceedings. 
Snyder, James and Catanese, Anthony. 1979. Introduction to Architecture. New York: McGraw-Hill Book Company.

Soeroto, Myrtha.2003. Dari Arsitektur Tradisional Menuju Arsitektur Indonesia. Jakarta: Ghalia Indonesia.

Wilkinson, Philip. 2013. Architecture Ideas: You Really Need to Know. China: Querus Inc. Wiryoprawiro, Zein. 1986.Arsitektur Tradisional Madura SUMENEP: dengan Pendekatan Historis danDeskriptif.Surabaya:Laboratorium Arsitektur Tradisional FTSP ITS. 